МАГОМЕДОВА Муслимат Алхилаевна - кандидат философскихнаук, старший научный сотрудник Регионального центра этнополитических исследований Дагестанского научного центра Российской академии наук (367025, Россия, Республика Дагестан, г. Махачкала, ул. М. Гаджиева, 45; тиslimatrci@mail.ru)

\title{
ОЦЕНКА ДЕЯТЕЛЬНОСТИ РЕГИОНАЛЬНЫХ ОРГАНОВ ВЛАСТИ ПО ИНФОРМАЦИОННО- ИДЕОЛОГИЧЕСКОМУ ПРОТИВОДЕЙСТВИЮ РЕЛИГИОЗНО-ПОЛИТИЧЕСКОМУ ЭКСТРЕМИЗМУ
}

Аннотация. В статье представлен анализ деятельности региональных органов власти по противодействию экстремизму. Особое внимание уделяется деятельности правоохранительных органов и Антитеррористической комиссии при главе Республики Дагестан в идеологическом противодействии религиозно-политическому экстремизму. Эмпирическую базу статьи составляют результаты экспертного опроса и интервью.

Ключевые слова: религиозно-политический экстремизм, Республика Дагестан, противодействие, органы власти, идеология

$\Pi$ рактическая деятельность по реализации государственной политики в области информационно-идеологического противодействия экстремизму осуществляется МВД, МИДом, МО, ФСБ, АТК, НАК Российской Федерации.

На заседании Совета по межнациональным отношениям В.В. Путин выделил важность проведения качественной информационной работы, чтобы члены Совета были в постоянном контакте с национальными объединениями, диаспорами и органами власти, давали объективную и достоверную оценку, доводили информацию с мест. «В мире, к сожалению, - собственно говоря, так было практически всегда - идет жесткая борьба за умы, за идеологическое и информационное влияние. С целью ослабить те или другие страны, создать для себя более выгодные конкурентные преимущества и в политике, и в экономике искусственно провоцируются конфликты, так или иначе связанные с национальными проблемами. Нам нужна постоянная, системная работа, которая защитила бы страну, нашу молодежь от этих рисков, служила укреплению гражданской солидарности и межнационального согласия» ${ }^{1}$.

В настоящее время на федеральном уровне принят и действует перечень документов, регламентирующих деятельность органов государственной власти по противодействию экстремизму и терроризму. Одним из основных документов в этом перечне является федеральный закон от 6 марта 2006 г. N 35-Ф3 «О противодействии терроризму», который определяет информационные, политические, экономические, социальные и иные методы борьбы с террористической угрозой. Кроме того, приняты Концепция противодействия терроризму в Российской Федерации, Концепция национальной безопасности Российской Федерации, Доктрина информационной безопасности Российской Федерации, Стратегия национальной безопасности Российской Федерации до 2020 года, Стратегия государственной национальной политики

1 Заседание Совета по межнациональным отношениям. Доступ: http://state.kremlin.ru/council/28/ news/46144 4.07.2014. (проверено 10.09.2018). 
Российской Федерации на период до 2025 года, Стратегия противодействия экстремизму в Российской Федерации до 2025 года, Комплексный план противодействия идеологии терроризма в Российской Федерации на 2013-2018 годы, закон о безопасности РФ, федеральный закон «О противодействии экстремистской деятельности».

В Республике Дагестан приняты закон «О запрете ваххабитской и иной экстремистской деятельности на территории Республики Дагестан», закон Республики Дагестан «О профилактике экстремистской деятельности в Республике Дагестан», утверждены государственная программа Республики Дагестан «Информационное противодействие идеологии экстремизма и терроризма в Республике Дагестан на 2014-2016 годы», программа Республики Дагестан «Комплексная программа противодействия идеологии терроризма в Республике Дагестан» на 2018-2020 годы.

Из перечисленных выше документов следует выделить Комплексный план противодействия идеологии терроризма в Российской Федерации на 2013-2018 годы, Стратегию противодействия экстремизму в Российской Федерации до 2025 года и Комплексную программу противодействия идеологии терроризма в Республике Дагестан на 2018-2020 годы. В них наравне с силовыми методами противодействия экстремизму основной упор в борьбе отводится идеологическому противодействию, а также уделяется внимание каналам распространения экстремистской идеологии.

Для эффективного обеспечения противодействия религиозно-политическому экстремизму необходим мониторинг организации деятельности субъектов противодействия экстремизму и терроризму.

Субъекты противодействия экстремизму - это федеральные органы государственной власти, органы государственной власти субъектов РФ, органы местного самоуправления, институты гражданского общества, организации и физические лица 1 . Основным инструментом органов государственной власти в противодействии религиозно-политическому экстремизму являются силовые структуры.

Каков уровень террористических угроз на сегодняшний день в республике? Какова эффективность деятельности различных правоохранительных органов по противодействию идеологии религиозно-политического экстремизма? Какова роль органов местного самоуправления, городских и муниципальных районов, сельских поселений, антитеррористической комиссии при главе республики и экспертного совета в идеологическом противодействии религиозно-политическому экстремизму? Ответить на эти вопросы в данном исследовании было предложено экспертам. В качестве респондентов выступили авторитетные специалисты, профессионально занимающиеся проблемами идеологического противодействия экстремизму и терроризму. Среди них можно выделить представителей органов государственного и муниципального управления, сотрудников правоохранительных органов, представителей Антитеррористического комитета РД, средств массовой информации, общественных организаций, научных работников. Всего было изучено мнение 20 экспертов посредством интервью и анкетного опроса. Ответы некоторых экспертов в данном тексте приведены в кавычках.

Следует отметить, что за последние 3-4 года в Республике Дагестан фактически прекратились террористические акты. Для выявления уровня террористических угроз в республике экспертам было предложено оценить его проявление

\footnotetext{
1 Стратегия противодействия экстремизму в Российской Федерации до 2025 года. Доступ: http:// www.scrf.gov.ru/documents/16/130.html (проверено 08.04.2015).
} 
по шкале от 0 до 10. По результатам опроса средний уровень террористических угроз в республике составил 4,2 балла.

В сокращении числа террористических актов в республике в последнее время большая заслуга принадлежит деятельности ФСБ и МВД. Террористические группировки подавлены на Северном Кавказе в целом. В задачи МВД фактически не входит идеологическое противодействие преступности. МВД призвано обеспечивать безопасность жизни граждан, государства; защищать имущество граждан и государства; обеспечивать общественный порядок и раскрывать преступления, совершенные против личности. Тем не менее среди приоритетных задач органов внутренних дел находится также и противодействие экстремизму. В Республике Дагестан эта практика началась в 1990-х гг., когда нужно было противодействовать экстремизму и терроризму; раскрывать преступления, связанные с похищениями людей. И эта традиция сохранилась до сих пор.

На заседаниях коллегий ФСБ и МВД России президент РФ В.В. Путин положительно оценил деятельность указанных выше структур в эффективном противодействии экстремизму и терроризму ${ }^{1}$.

В целях определения эффективности деятельности правоохранительных органов по противодействию идеологии религиозно-политического экстремизма экспертам был задан вопрос: «Какова, на Ваш взгляд, эффективность различных правоохранительных органов по противодействию идеологии экстремизма и терроризма в Республике Дагестан? Оцените ее, пожалуйста, по шкале от 0 (полное отсутствие эффективности) до 10 (максимально высокая эффективность). Дайте свою оценку деятельности этих органов».

Ниже приведены ответы по каждой правоохранительной структуре (см. табл. 1). таблица 1

\section{Оценка эффективности деятельности различных правоохранительных органов по противодействию идеологии экстремизма и терроризма в Республике Дагестан, 2018 r.}

\begin{tabular}{|l|c|}
\hline \multicolumn{1}{|c|}{ Правоохранительные органы } & Средние оценки в баллах \\
\hline Органы МВД & 6,1 \\
\hline Органы ФСБ & 6,8 \\
\hline Органы прокуратуры & 3,85 \\
\hline Органы Следственного комитета & 3,2 \\
\hline Органы судебной власти & 2,4 \\
\hline
\end{tabular}

Для сравнения приведем данные экспертного опроса, проведенного автором в 2016 г. (см. табл. 2).

По данным приведенных таблиц можно утверждать, что в регионе наиболее эффективно противодействуют идеологии экстремизма и терроризма органы ФСБ. На 2-м месте находятся органы МВД, а на последних местах находятся органы Следственного комитета и судебной власти.

Угрозу для общества на сегодняшний день представляет деятельность террористов-одиночек. На наш взгляд, это упущение в идеологическом противодействии. Это очень тонкая и кропотливая работа. Для ее реализации нужно гораздо меньше денег, чем тратится на контртеррористические операции (KTO).

1 Расширенное заседание коллегии Федеральной службы безопасности. Доступ: http://kremlin. ru/d/56977 (проверено 06.03.2018); Расширенное заседание коллегии МВД России. Доступ: http:// www.nykhas.ru/461986/rasshirennoe-zasedanie-kollegii-mvd-r-2/ (проверено 04.07.2018). 
Таблица 2

\section{Оценка эффективности деятельности различных правоохранительных органов по противодействию идеологии экстремизма и терроризма в Республике Дагестан, 2016 r.}

\begin{tabular}{|l|c|}
\hline \multicolumn{1}{|c|}{ Правоохранительные органы } & Средние оценки в баллах \\
\hline Органы МВД & 4,4 \\
\hline Органы ФСБ & 5,6 \\
\hline Органы прокуратуры & 3,27 \\
\hline Органы Следственного комитета & 3,4 \\
\hline
\end{tabular}

К сожалению, КТО на Северном Кавказе были выгоднее определенному кругу лиц, чем идеологическая и профилактическая работа.

В ходе экспертного опроса многие респонденты отмечали такие отрицательные моменты в деятельности силовых структур, которые усугубляют ситуацию с распространением экстремистских настроений в молодежной среде. В данном случае речь идет о так называемом профилактическом учете. Отсутствие легитимности проводимых действий по профилактике вызывает раздражение у населения, чем ловко пользуются экстремисты. Это противоречит положению закона «О профилактике экстремистской деятельности в Республике Дагестан». По мнению некоторых экспертов, тем, кто находится в списках профилактического учета, приписывают преступления, которые они не совершали. Признания в несовершенных преступлениях добиваются часто силовыми методами. Руководитель Центра социально-экономических исследований регионов RAMCOM Денис Соколов отмечает: «В Дагестане - и не только в Дагестане - за полтора десятилетия формирования правоохранительных практик по борьбе с терроризмом и экстремизмом КТО, массовые аресты в мечетях, постановка на учет, похищения людей, организация уголовных дел на основе оговора под давлением, фальсификации улик или самооговора под пытками сложились в самоподдерживающуюся систему. Эта машина функционирует в интересах большой группы работников правоохранительных органов» 1 .

Следует отметить, что в начале 2018 г. Совет при Президенте РФ по развитию гражданского общества и правам человека 4 дня принимал граждан в Дагестане. Люди обращались за помощью по разным вопросам.

Институтом, призванным обеспечивать координацию позиций и действий власти и общества в борьбе против нарушения прав человека, экстремизма и терроризма, является Антитеррористическая комиссия в Республике Дагестан, а также районные и городские антитеррористические комиссии, оперативные группы по противодействию терроризму на местах. С целью изучения роли данной комиссии в республике респондентам был задан в открытой форме следующий вопрос: «Как Вы оцениваете роль Антитеррористической комиссии при главе республики и экспертного совета в идеологическом противодействии религиозно-политическому экстремизму и терроризму?» Ее было предложено оценить по шкале от 0 до 10 баллов.

Респонденты высоко оценили роль Антитеррористической комиссии в республике: средний уровень оценки составил около 8 баллов. Ниже приведены высказывания нескольких экспертов.

\footnotetext{
1 Соколов: «антитеррористический комбайн» ломает жизни дагестанцев. Доступ: http://www.kavkazuzel.eu/articles/antiterroristicheskij_kombain/ (проверено 26.06.2018).
} 
«Роль АТК в республике очень высокая, это единственная структура, которая реально и эффективно работает. Ее роль высока, потому что они фактически подгоняют и руководителей, и глав муниципалитетов. Но в их деятельности присутствует и некий формализм. Что касается экспертного совета, то деятельность этого совета не так эффективна, как хотелось бы. На мой взгляд, каждый отдельный член совета сам по себе был бы более эффективен, чем в рамках этого экспертного совета».

«АТК является координатором работы в идеологическом противодействии религиозно-политическому экстремизму в республике. В последнее время эту деятельность можно оценить на 10 баллов. Недавно представители НАК были в нашем районе и поставили хорошую оценку нашей работе в этом направлении».

В каждом муниципальном образовании республики функционируют антитеррористические комиссии, и ответственными за эту работу являются заместители глав районов по общественной безопасности. Сотрудники аппарата АТК в РД совместно с представителями Межведомственной рабочей группы по координации деятельности в области противодействия терроризму на территории Республики Дагестан - сотрудниками аппарата Национального антитеррористического комитета на регулярной основе, с выездом на места осуществляют контроль и анализ эффективности деятельности антитеррористических комиссий в муниципальных образованиях, оказывают им необходимую консультативно-методическую помощь. На заседаниях АТК в РД с отчетами о проделанной работе по противодействию экстремизму и терроризму выступают представители антитеррористических комиссий в муниципальных образованиях - главы муниципальных образований и руководители заинтересованных министерств и ведомств, а в муниципальных районах главы сельских поселений.

По результатам экспертного опроса, проведенного автором в 2018 г, деятельность правоохранительных структур в республике по 10-балльной шкале была оценена выше среднего. Благодаря слаженной и оперативной работе сотрудников правоохранительных органов, в последние несколько лет республика фактически живет без террористических актов. В ходе исследования выявились также и отрицательные моменты в деятельности силовых структур. Это так называемый профилактический учет, применение насилия по отношению к задержанным гражданам.

Эффективная работа по информационно-идеологическому противодействию в республике ведется и представителями Антитеррористической комиссии при главе республики. Средний уровень оценки по 10-балльной шкале по результатам исследования составил около 8 баллов.

Преодоление экстремизма и терроризма в республике возможно на основе комплексного подхода, который включает в себя деятельность органов государственной власти, органов местного самоуправления, институтов гражданского общества. Идеологическое противодействие экстремизму и терроризму должно быть трехуровневым: стратегический уровень позволит устранить причины терроризма, оперативный уровень позволит предотвратить и ликвидировать возможность терроризма, тактический уровень позволит противодействовать террористическим актам на всех этапах [Казиев, Юсупова 2018].

Отмечая актуальность проблем информационно-идеологического противодействия религиозно-политическому экстремизму в Республике Дагестан, считаем необходимым осуществить следующие меры.

1. Повысить эффективность деятельности правоохранительных органов по предупреждению экстремизма и терроризма. Повысить ответственность за 
соблюдение законности при проведении оперативных и следственных мероприятий в ходе противодействия экстремизму.

2. Усилить принимаемые меры по перекрытию каналов финансирования экстремистов и террористов.

3. Считать приоритетной задачей идеологического противодействия экстремизму создание в обществе целостной системы духовной безопасности, обеспечивающей невосприимчивость к идеологии экстремизма.

4. Муниципальным органам власти уделить особое внимание воспитанию населения в духе национальной и религиозной терпимости. Органам местного самоуправления вести целенаправленную работу по организации культурнопросветительского, социально полезного и спортивно-оздоровительного досуга молодежи.

\section{Список литературы}

Казиев Н.Э., Юсупова Г.И. 2018. Рекомендации по привлечению институтов гражданского общества к мероприятиям по противодействию идеологии терроризма, проводимым Антитеррористической комиссией в Республике Дагестан. - Дагестан: поиск эффективных мер борьбы с экстремизмом и терроризмом: сборник докладов членов экспертного совета при Антитеррористической комиссии в Республике Дагестан (под общ. ред. К.Г. Ланды). Махачкала: ИД «Дагестан». C. $123-138$.

\section{THE ASSESSMENT OF THE ACTIVITIES OF REGIONAL AUTHORITIES ON INFORMATION AND IDEOLOGICAL COUNTERACTION TO RELIGIOUS AND POLITICAL EXTREMISM}

Abstract. The article presents an analysis of the activities of regional authorities to counter extremism. The author pays special attention to the activities of law enforcement agencies and the Anti-terrorist Commission under the Head of the Republic of Dagestan in ideological counteraction to religious and political extremism. The empirical base of the article consists of the results of an expert survey.

Keywords: religious and political extremism, Republic of Dagestan, counter measure, government body, ideology 